\title{
DESIGN AND DEVELOP A MODEL FOR SALINE MONITORING SYSTEM
}

\author{
Tanvi Kulkarni, Mr. Avinash Devare, Sayli Zende, Shubhada Yadav, Ajay Biradar \\ Dept. of Computer Engineering, Trinity Academy of Engineering, \\ Pune, Maharashtra, India
}

\begin{abstract}
Nowadays, the entire life of each and every person becomes more hectic due to the heavy load of work. Due to increase of work load, people neglect their health and it may cause more harmful to their health in future. So many health care systems are developed to continuously monitor their blood pressure, haemoglobin, sleep rate, diabetes etc. Sometimes people feel dehydration that's why they need to fed saline to improve their health. So, we develop saline monitoring system which continuously monitors level of saline in absence of any hospital staff. The main purpose of this system is to automatically track the saline level of patient using Arduino nano and whole system is remotely controlled by an Android OS smart phone. In hospitals, it is not possible that nurse will monitor each and every patient. It may harm to nerves of patients, so to overcome this situation we develop proposed system. Main aim of system is that to monitor the saline level and notify the current level of the saline to the nurse. And when the saline gets finished system automatically stops the flow of saline with the help of spring.
\end{abstract}

\section{Keywords: Arduino Nano, Load Cell, Saline, Spring.}

\section{INTRODUCTION}

In current era, most of the technology are evolving, and the advanced world is progressing more and more. One of the most useful technology is IoT. Which is used for interconnecting many more devices and sensors to develop intelligent systems. There are many applications of IoT like home automation systems, health management systems etc. These health monitoring systems are used to monitor blood pressure, HBs, diabetes etc. In most of the hospitals there are "smart beds" which are used to check sleep rate and also used to check pressure, temperature of body. So, similarly we developed one system where IoT plays an important role for monitoring saline system. Whenever a particular patient feels dehydration at that time saline is fed to them. Continuous monitoring of saline level is quite important job, any mistake done at the time of monitoring, in future patient may faces any consequences or problems. It may harmful to their health or it can damage their nerves. So, monitoring of saline level is the responsibility of any hospital staff such as Doctors, nurses, care-taker. In most of the situations hospital staff cannot monitor saline continuously, it gets harmful results. So, to avoid this situation proposed system is used for monitoring level of saline automatically. Saline stand contains load cell which helps to check the weight of saline bottle. After completion of saline it just generates alarm and also generates message on LCD or Android App. If no hospital staff is there then it stops the flow of saline by using pinch. The advantage of this system is that nurse can efficiently work and give proper time to every patient.

\section{EXISTING APPROACH}

In the existing scenario of health care management system, Arduino micro-controller is used for the processing and programming. To check the critical level of saline they are using IR sensors. IR sensor was also sensing the saline completion status. In the previous system clamp is attach with the spring to pinch the saline pipe to stop the reverse flow of the liquid. There was an LCD in the control room which shows the number of patient room for the quick recovery.

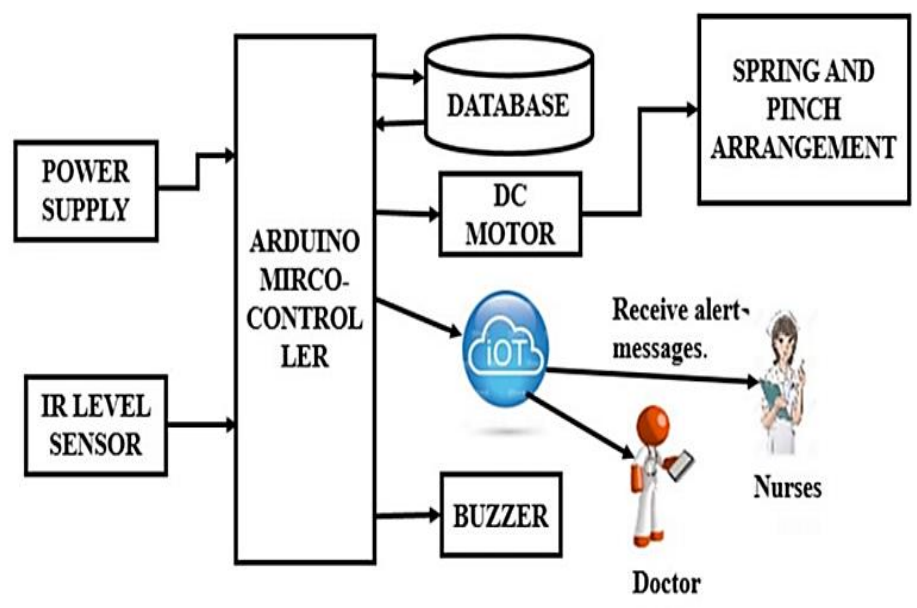

Figure 1: Architecture of existing system

\section{SySTEM ARCHITECTURE}

In proposed system saline is automatically monitored by using the Internet of Things. We are using most of the hardware devices which are connected to Arduino Nano micro controller. The hardware devices include - Power Supply, NRF Module, Load Sensor, HX711, EEPROM, LED, Buzzer etc. All these devices fixed into Arduino to monitor saline. Here we are using load cell, is used to measure the weight of saline which generates analog 
signals that can be transmitted to HX711. HX711 receives analog signals from load cell and it amplifies those signals and transfer to micro controller. NRF Module is used when, the level of saline goes below threshold value then this value is sent over this module to the receiver section. When, power goes off at that time last load cell value of saline is stored in EEPROM. Arduino Nano micro controller is attached to the saline stand so that it can easily monitor the level of saline. Buzzer and LED these are output devices which, depends upon the data comes from NRF Module i.e. when level of saline goes below threshold then buzzer and LED will be generated. So, all this information will be stored on local server of particular hospital. This information will be display on LCD/Android App by fetching all information from server. It also informs nurses or doctors via generating alert message on application.

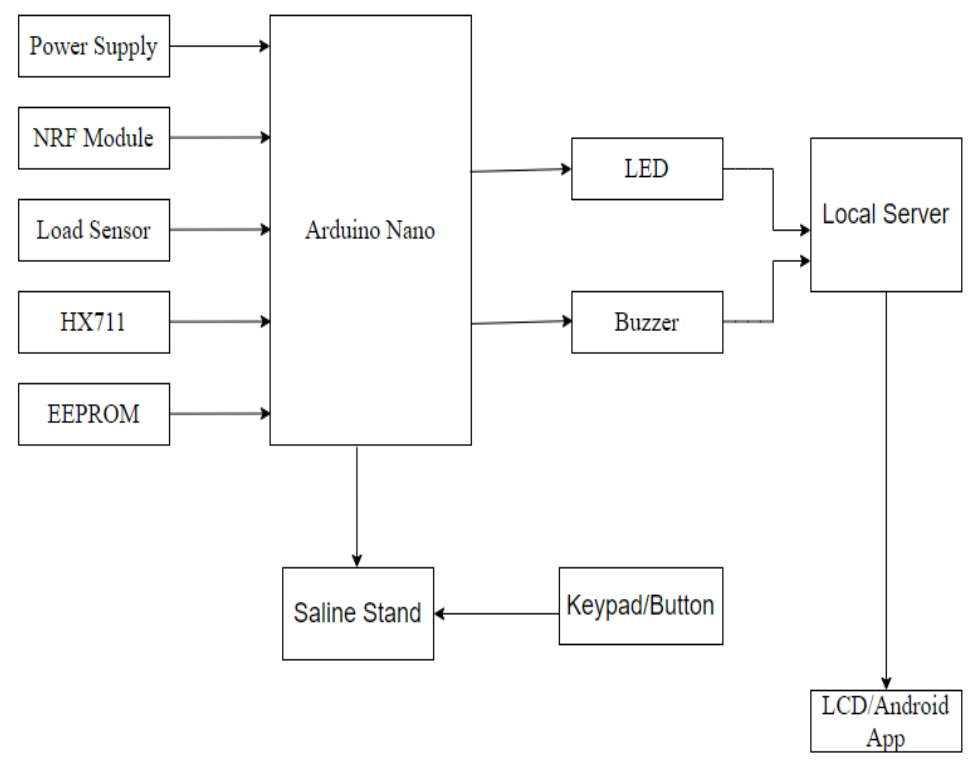

Figure 2: Block Diagram of Proposed System

\section{WORKING OF SYSTEM}

\section{Module 1 (Weight Calculation) -}

Actual weight of the saline is considered as a maximum weight and $25 \%$ of that maximum weight is considered as a minimum weight. Which is also displayed on the LCD as well as it displays the weight of saline when the level of saline decreases.

\section{Module 2 (EEPROM Controlling) -}

EEPROM stands for "Electrically Erasable Programmable Read-Only Memory". EEPROM is used to store the reference value of saline level i.e. it stores the initial value as well as the threshold value. In case of power failure or controller restart it will save the reference data due to EEPROM.

\section{Module 3 (Alarm Generation and Alert Message) -}

This module generates an alarm when saline reaches to the threshold Value. At the same time, it sends message to the nurse by using android application.

\section{Module 4 (Pinch the Pipe of Saline) -}

Spring and DC motor is also attached to the pipe of the saline. If nurse is not available on time then spring is used to pinch the saline pipe to stop the flow of liquid.

Module wise working of system is shown in figure 2 which is located below. This diagram describes the working of entire system.

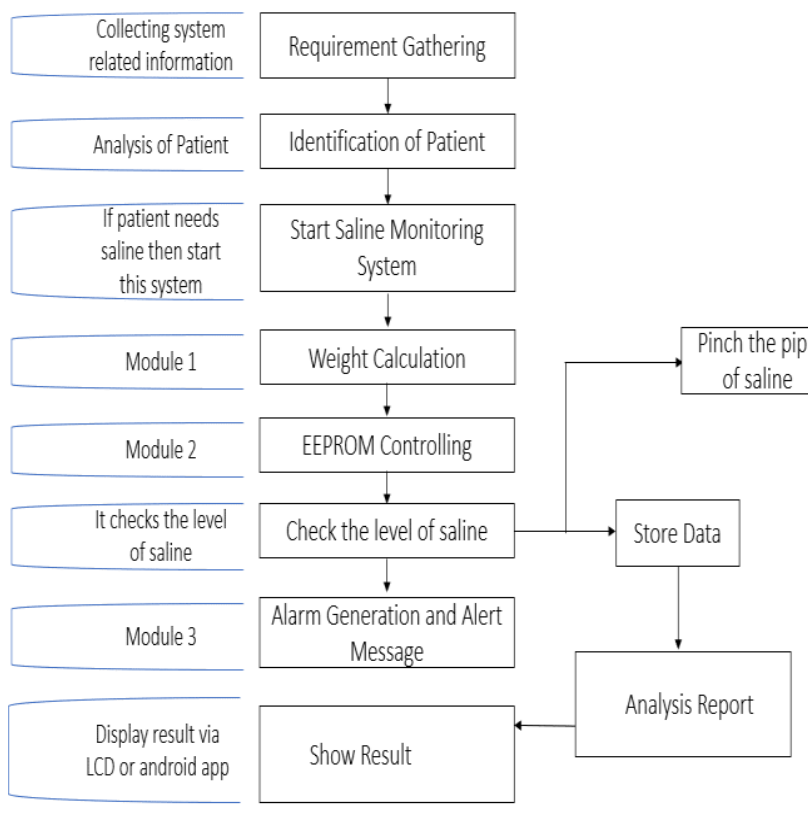

Figure 3: Module of System

\section{RESUlts}

Calculating the result for $1000 \mathrm{ml}$ of saline bottle. $1000 \mathrm{ml}$ of fluid is fed to a patient which runs for $7 \mathrm{hrs}$. So, we calculate the drip rate.

Formula to calculate drip rate: -

$$
\text { Drip Rate }=\frac{\text { weight }(\text { volume }) \text { of } \text { fluid }}{\text { time }}
$$

Solution: -

$$
\begin{aligned}
& \text { Volume }=1000 \mathrm{ml} \\
& \text { Time }=7 \mathrm{hrs}
\end{aligned}
$$

So, we put these two values into Drip Rate formula- 


$$
\text { Drip Rate }=\frac{1000 \mathrm{ml}}{7 \mathrm{hrs}}=142.86 \mathrm{ml} / \mathrm{hr}
$$

Therefore, patient will receive $142.86 \mathrm{ml}$ of fluid per 1 hour.

Following table 1 shows the calculation of drip rate of fluid per hr.

\begin{tabular}{|r|r|r|}
\hline Weight of Saline & Hours & Drip Rate of fluid per Hr. \\
\hline 1000 & 7 & 142.86 \\
\hline 857.14 & 6 & 142.86 \\
\hline 714.29 & 5 & 142.86 \\
\hline 571.43 & 4 & 142.86 \\
\hline 428.57 & 3 & 142.86 \\
\hline 285.71 & 2 & 142.86 \\
\hline 142.86 & 1 & 142.86 \\
\hline 0.00 & 0 & 0.00 \\
\hline
\end{tabular}

Table 1: Drip Rate Calculation

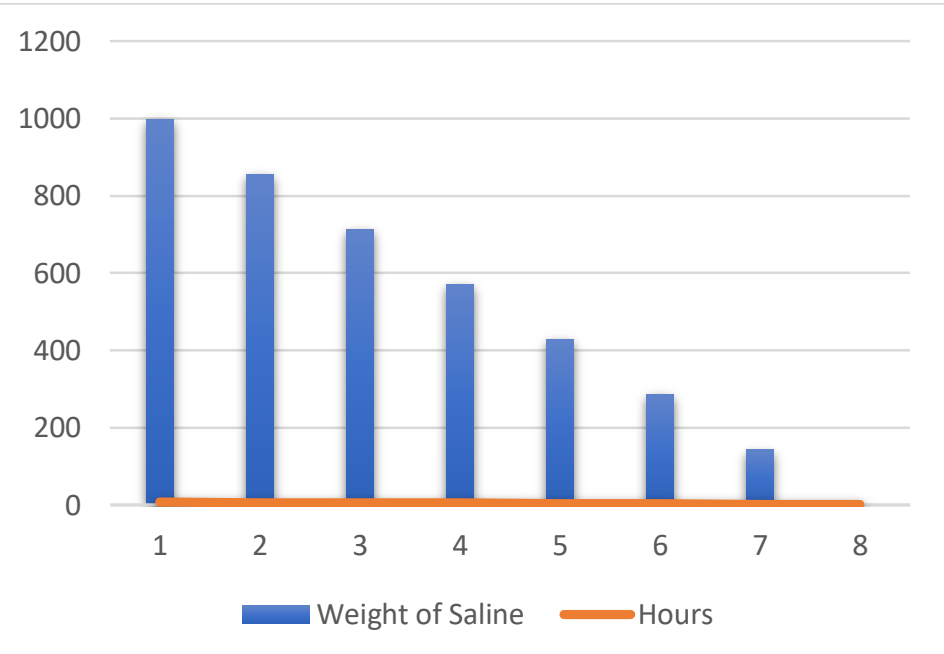

Figure 4: Weight of saline graph

This above figure 4 indicates the weight of saline proportional to an hour. It shows the graph of saline weight in decreasing manner.

\section{Drip Rate of fluid per $\mathrm{Hr}$.}

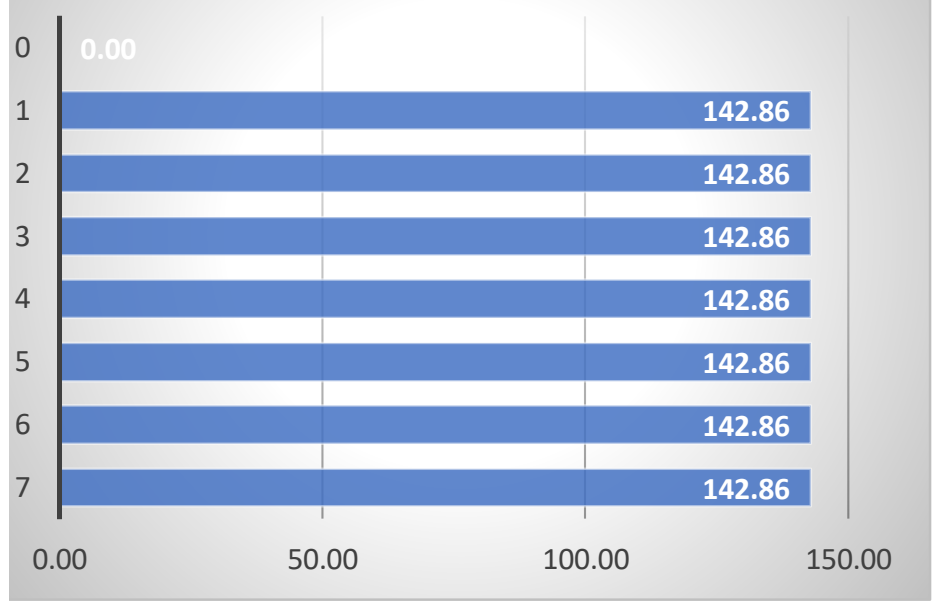

Figure 5: Drip rate graph

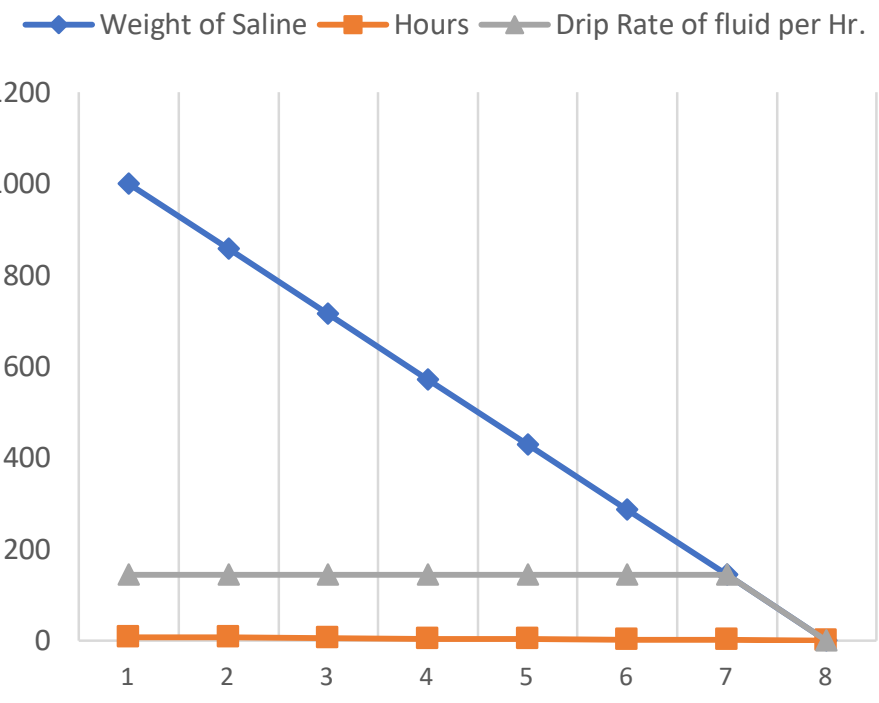

Figure 6: Graph of Drip Rate Calculation

Table 1 is represented with the help of this graph which shows in figure 6 . It shows the relationship between weight of saline, hours and drip rate of fluid per hr.

Now, Calculate the threshold value of weight of saline. Here we are considering $25 \%$ as a threshold value.

Formula to calculate threshold value: -

$$
\text { Threshold value }=\text { weight of saline } * \frac{25}{100}
$$


International Journal of Engineering Applied Sciences and Technology, 2020

Vol. 5, Issue 1, ISSN No. 2455-2143, Pages 497-501

Published Online May 2020 in IJEAST (http://www.ijeast.com)

\begin{tabular}{|r|r|r|r}
\hline Weight of Saline & Hours & $\begin{array}{r}\text { Drip Rate of fluid per } \\
\text { Hr. }\end{array}$ & Threshold vi \\
\hline 1000 & 7 & 142.86 & \\
\hline 857.14 & 6 & 142.86 & 17 \\
\hline 714.29 & 5 & 142.86 & 14 \\
\hline 571.43 & 4 & 142.86 & 10 \\
\hline 428.57 & 3 & 142.86 & 7 \\
\hline 285.71 & 2 & 142.86 & 14 \\
\hline 142.86 & 1 & 142.86 & \\
\hline 0.00 & 0 & 0.00 & \\
\hline
\end{tabular}

\section{CONCLUSION}

The proposed system designed by using Internet of things. The entire system works automatically, so, it didn't require the human interaction. Generally, in hospitals there be a nurse, doctor or caretaker who manually checks the status of saline. In some cases, nurse was not available to monitor the saline at that time if the saline is finished and still it attached to the patient's body then, it may harm to the patient. In this situation the proposed system works automatically, and saves the patient life. The system will be advantageous at night as there will be no such requirement to the nurse to check the patient saline every time. Since the alert message will be sent to the doctor, nurse or caretaker when saline reaches to the critical level, and it also pinches the saline pipe at that time to stop the flow of saline. It will be helpful in urban as well as rural areas where the human power is less at an affordable cost. The system will be reduced stress of doctors, nurses or caretakers to continual monitoring.

shown as Red color in abo saline reaches to this critical threshold value then this proposed system generates an alarm and informs the nurse or doctor by generating alert message through android application.

When saline reaches to 0 which shown as Yellow color in above table 2, at that time, it pinches the saline pipe so, that air cannot passes through the pipe of saline. If air flows through it then it may cause harm to patient's health.

Above table 2 is represented in the form of graph. Which is shown below.

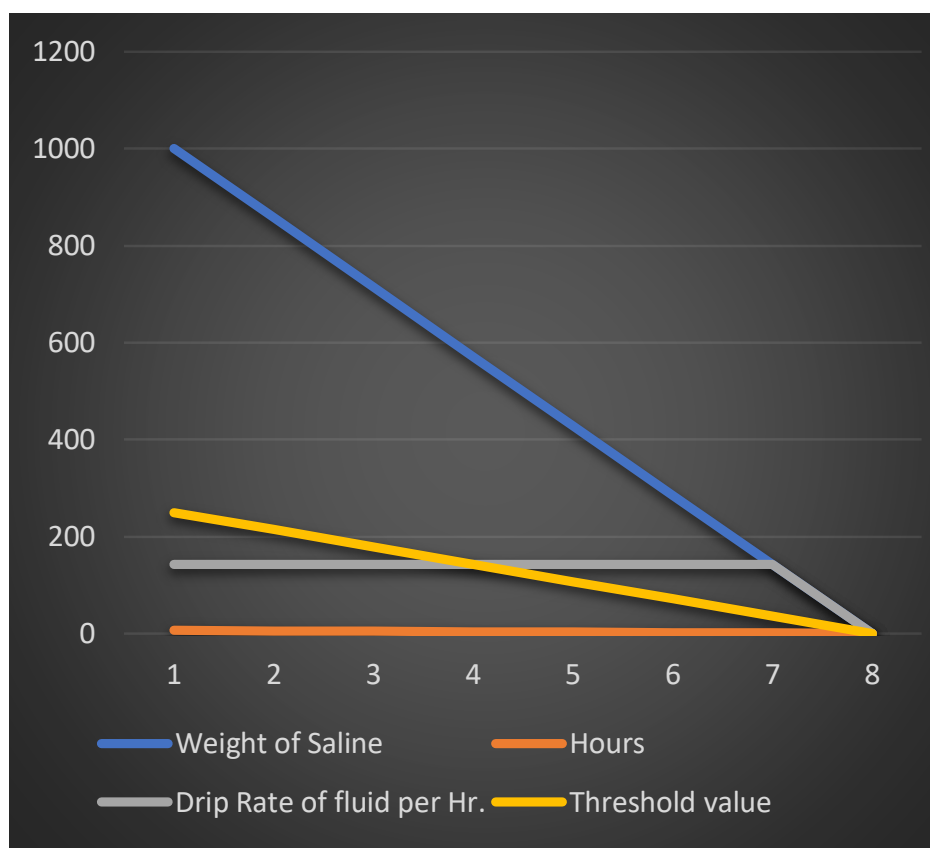

Figure 7: Graph of Threshold value Calculation

3. Santos F.S., Perkusich Angelo and Almeida Hyggo O.(2014) "Standard-based and Distributed Health Information Sharing for mHealth IoT Systems" IEEE

HEALTHCOM 2014 - The 2nd International

In our endeavour to achieve the success in completing our project "Design and Develop A Model for Saline Monitoring System Using IoT" in the Fourth Year Computer Engineering. We take this opportunity to express our deep sense of gratefulness to our guide Prof. A. S. Devare for his valuable guidance and kind cooperation throughout the period of work. We express our thankfulness to all teachers and staff of computer department for timely help in project preparation. Finally, special thanks to our friends, family members and all others who have helped us directly or indirectly for successful completion of this work.

\section{REFERENCES}

1. Umchid S., Kongsomboom P., Buttongdee M.(2018) "Design and Development of a Monitoring System for Saline Administration " Proceedings of the World Congress on Engineering 2018 Vol I WCE 2018, July 4-6, 2018, London, U.K.

2. Kalaivani P., Thamaraiselvi T., Sindhuja P. and Vegha G.(2017)'Real Time ECG and Saline Level Monitoring System Using Arduino UNO Processor " Asian Journal of Applied Science and Technology (AJAST) Volume 1, Issue 2, Pages 160-164. 
Workshop on Service Science for e-Health (SSH 2014).

4. Chidgopkar Mansi G., Phatale Aruna P.( 2015) "Automatic and low cost saline level monitoring system using wireless bluetooth module and cc2500 transreceiver " IJRET: International Journal of Research in Engineering and Technology September2015, Volume: 04 Issue: 09.

5. Baviskar Darshana, Patil Pooja , Bhatambre Shivlila (2018.) "IOT based saline level monitoring system " Open access international journal of science and engineering(oaijse), Volume 3, Issue 11 November2018.

6. Gupta S. , Kulkarni M. , Kulkarni Y.(2018) "Smart Saline Monitoring System Using Load Cell and RF Sensor " International Research Journal of Engineering and Technology (IRJET), june2018, Volume: 05 Issue:06.

7. Sayyad Afratasneem R., Nigade Sunita, Patil Rutuja, Jadhav P. N.,Mujawar Sakib. R (2016)"Design and Development of Saline Monitoring System Using Load cell" International Research Journal of Multidisciplinary Studies.

8. Vaishnav Khushboo,Haidarali Nargees Bano,Swamy Neha(2017) "IoT based saline level monitoring system".International Journal of Innovations \& Advancement in Computer Science (IJIACS ).

9. Ghosh Debjani, Agrawal Ankit, Prakash Navin , Goyal Pushkal (2018)"Smart Saline Level Monitoring System Using ESP32 And MQTT-S"2018 IEEE 20th International Conference on e-Health Networking, Applications and Services (Healthcom).

10. Deshmukh Rutuja, Jadhav Kshitija , Borude Tejaswee,Lanke Harshada(November 2019)"A Survey Paper on Patient Health and Saline Level Monitoring System using IoT "International Journal of Engineering Research \& Technology (IJERT), ISSN: 2278-0181,IJERTV8IS110407,Vol. 8 Issue 11.

11. Sheeba P. Pearline, Anushree N.,Aishwarya L.(November 2016) "Saline Infusion Level Detection and Heart Rate Monitoring System(IJRASET).

12. Malleswaei B.,Varma P. Vijay,Dr.Venkatanam N.(2018)"Smart saline level monitoring system using IOT "International Journal Of Engineering \& Technology(IJET),Vol7,no.2.7,Pg.No.817-19,2018. 